\title{
unindra
}

Universitas Indraprasta PGRI

Address: Jl. Nangka No. 58 C (TB. Simatupang), Kel. Tanjung Barat, Kec. Jagakarsa, Jakarta Selatan 12530, Indonesia.

+62 21 7818718-78835283; url: www.unindra.ac.id; cultural.syndrome@unindra.ac.id

\section{The Art of Adaptation: From Folk Literature to the} Age-Appropriate Visual Media

\section{Santi Sidhartani ${ }^{1}$, \\ Muhammad Iqbal Qeis *2, \\ Dendi Pratama ${ }^{3}$}

Departement of Visual Communication Design, Universitas Indraprasta PGRI ${ }^{123}$

Correspondence regarding this article should be addressed to: Muhammad Iqbal Qeis, qeis.m.i@gmail.com .

\section{Article History}

Received : 18-06-2019

Revised : 20-06-2019

Accepted : 23-06-2019

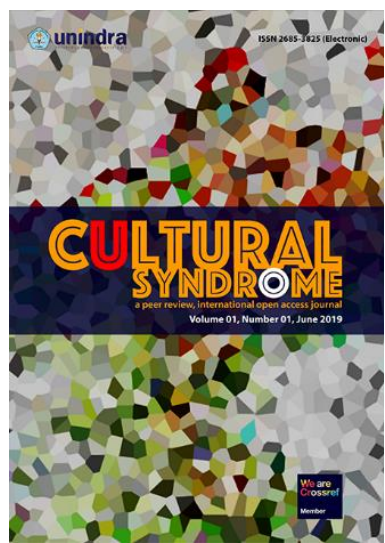

Cultural Syndrome

a peer review, internasional open access journal e-ISSN: 2685-3825

Editor: (D)Ahmad Faiz Muntazori

Publication details, including author guidlines https://journal.unindra.ac.id/index.php/cusy/ about/submissions\#authorGuidelines

\section{How to cite this article (MLA 8th)}

Sidhartani, Santi, Muhammad Iqbal Qeis, and Dendi Pratama. "The Art of Adaptation: From Folk Literature to the Age-Appropriate Visual Media." Cultural Syndrome, Vol.1, No.1, 2019, pp. 53-60., doi.org/10.30998/cs.v1i1.22

The readers can link to article via https://doi.org/10.30998/cs.v1i1.22

\section{SCROLL DOWN TO READ THIS ARTICLE}

Universitas Indraprasta PGRI (as Publisher) makes every effort to ensure the accuracy of all the information (the "Content") contained in the publications. However, we make no representations or warranties whatsoever as to the accuracy, completeness, or suitability for any purpose of the Content. Any opinions and views expressed in this publication are the opinions and views of the authors, and are not the views of or endorsed by Universitas Indraprasta PGRI. The accuracy of the Content should not be relied upon and should be independently verified with primary sources of information.

\section{(c) $(1) \&$}

This work is licensed under a Creative Commons Attribution-NonCommercial 4.0 International License.

Copyright by Santi Sidhartani, Muhammad Iqbal Qeis, Dendi Pratama (2019)

The authors whose names are listed in this manuscript declared that they have NO affiliations with or involvement in any organization or entity with any financial interest (such as honoraria; educational grants; participation in speakers' bureaus; membership, employment, consultancies, stock ownership, or other equity interest; and expert testimony or patent-licensing arrangements), or non-financial interest (such as personal or professional relationships, affiliations, knowledge or beliefs) in the subject matter or materials discussed in this manuscript. This statement is signed by all the authors to indicate agreement that the all information in this article is true and correct 


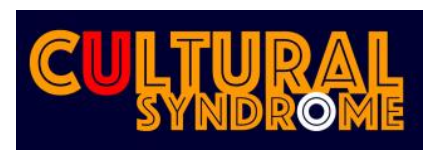

Vol.1, No.1, 2019, pp. 53-60

e-ISSN: 2685-3825

https://doi.org/10.30998/cs.v1i1.22

\title{
The Art of Adaptation: From Folk Literature to the Age-Appropriate Visual Media
}

\author{
Santi Sidhartani ${ }^{1}$, Muhammad Iqbal Qeis ${ }^{2}$, Dendi Pratama ${ }^{3}$ \\ Universitas Indraprasta PGRI, Jakarta ${ }^{123}$
}

\begin{abstract}
The art of adaptation is a process to translate the art form from one media into another. Folklores as a form of media that express the experience and beliefs that was shared amongst the society living in a certain region are usually passed down from the older generation to the younger generation by word of mouth or though oral tradition. Although some of the folklores have been compiled and translated in the form of folk literature and are transcribed in books and written media, these folk literatures generally consist of texts with little visuals. This is a problem since the main target of folklores is usually children who are more attracted to colorful and rich world of illustration rather than a text-filled literary book. This paper aims to describe the process involved in the art of adaptation that transforms folk literature into a more age-appropriate visual mediafor children as an effort to preserve the tradition of folklore in society. The conclusion shows that the process involved a deep understanding of the folklore, not only the story but also the characters and the background location depicted in order to design an appealing visual media that retains the cultural values shared within the society.
\end{abstract}

Keywords: the art of adaptation; folklore, folk literature; visual media; children

Correspondence author: Muhammad Iqbal Qeis, qeis.m.i@gmail.com, Jakarta, and Indonesia

(c) (1) (3)

This work is licensed under a CC-BY-NC

\section{Introduction}

Folklore is defined by Dananjaya as a collective culture that is transmitted and inherited throughout generations either in the form of oral tradition or accompanied by gestures or mnemonic devices (Danandjaja). Folklore then is an expression of a society. It is a central act for social interaction within community and to express the shared 
cultural values. However, though Dananjaya defined that one of the characteristics of folklore is the oral transmission, Blank argued that folklore is not limited to orality (Blank). So the folklore still retains its identity as folklore even when it was transmitted through printed media or electronic devices. Blank further argues that what constitutes as folklore lies in its aesthetical expression rather than the transmission or the means of communications.

As a form of cultural heritage, folklore may start as an oral tradition, however many folklore has been compiled and transcribed into a written media in the form of folk literature. With the changes and the advancement of information technology, there is an urgent need to bring the folklore into more than just folk literature by adapting them into the current media in order to introduce, to communicate the cultural and moral values, as well as to preserve the folklore as an intangible cultural asset to the younger generation. This is why it is needed to develop the folklore outside of written media or folk literature by implementing the art of adaptation.

The art of adaptation is a process to translate the art form from one media into another. Cavallaro stated that the art of adaptation transcends the original reference by widening the horizon through complex processes of aesthetic and an intricate mix of

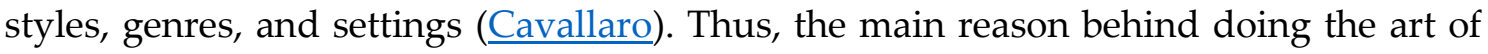
adaptation is to widen the horizon so that the original material can reach and appeal to another audience. As visual culture has been widely embraced by the society since the dawn of the internet and smartphone with high connectivity, many children nowadays are more prone to the information presented in visual media rather than written media. Gillespie wrote that the art of adaptation can express classic ideas to speak to the new generation (Gillespie). Based on the problem stated before, there is an urgent necessity to adapt the already transcribed folk literature for the younger generations. This paper aims to describe the process involved in the art of adaptation that transforms folk literature into a more age-appropriate visual media as an effort to preserve the tradition of folklore in society. Thus, the transmission of moral and cultural values from older generation to younger generation can be preserved by making the children as the target audience in adapting the folk literature into a visual media.

\section{Methods}

This study used descriptive qualitative methods that will present the results of studies from selected media to explain how the art of adaptation can be used to convey stories and messages contained in folklore. In this study an animated film was titled "Bawang Merah Bawang Putih" by Ahmad Khan Hakim. In this media, we will discuss how the choice of visual elements in animated films such as illustrations, colors, and shapes related and influenced story and message delivered to the children. The results of this study can provide an explanation of how to select and process design elements in a visual media that can optimize the function of storytelling by considering the needs and abilities of children in processing messages. 


\section{Result and Discussion}

According to Bascom in Dananjaya folklore in the form of prose can be divided into three groups, that are myth, legend, and folktale (Danandjaja).

1. Myth is a story that is considered truly happening and is considered sacred by the owner of the story. Myth is emphasized by villages or demigod beings. Stories and events in myth are described as occurring in another world or in a world that is not as we know it today.

2. Legends are considered truly happened but are not considered sacred. The characters in legend are humans, although there are times when they have extraordinary qualities and are also often helped by magical creatures. The place of occurrence of the myth is in the world as it is known today.

3. Fairy tales are considered as a story that never happened and are not bound with any time or any place.

Folklore contains many values that can be exemplified by the message conveyed in the story, this is as stated by Setyawan et al. that there have been many studies of folklore as a product of culture which are associated with noble values from the community who owned it, so that folklore can be a guide and example in life (Setyawan et al.). One of the functions of folk literature for children is to educate by transmitting the moral and cultural values. Therefore, the clarity of the story becomes a main aspect in the process of adaptation. The understanding of the whole story and the cultural and moral values behind becomes crucial in adapting folk literature into the visual media. In that sense, the illustration developed for the visual media needs to help children to understand the whole story while also piqued their interest.

Lidwell in Adi explains that storytelling is a way of delivering messages that are very humanistic and have been used by people from generation to generation in the delivery of knowledge up to now. In a visual message delivery, the storytelling approach can attract the reader's attention. A visual message that conveyed through a design or illustration that tells a story can certainly form emotions so that it affects the visual experience of the reader ( $\underline{\mathrm{Adi}})$. This explanation can strengthen the understanding of the importance role of an illustration in delivering story in the folklore.

In the process of designing the illustration as a part of the art of adaptation, many aspects of the story need to be examined so that it can bring the idea behind the story of folk literature into a tangible form. These aspects will be associated with the use of visual elements to describe the elements of the story in it. These said aspects include:

1. Plot or storyline. This refer to how the story is being told and whether it follows a certain pattern or bound within a particular time such as a story happened in a long forgotten past or in an unimaginable future.

2. Characters and their characterization. This element will affect in how to depict characters within the story visually so that it will match the overall message.

3. Place or background setting. This refers to where the story took place, whether in real world or imaginary ones, and it will affect in the process of depicting the place based on the intended message. 
All three aspects carry weight in the process of adaptation, especially when making an age-appropriate visual media for children since within the children's minds, not only cognitive aspects but also emotional aspects need to be emphasized so that they will be interested in the media and pay full attention to it. Since the resulting visual media targets children as the main audience, the three aspects of the story need to be carefully presented in order for children to memorize the story better, and ultimately, store the values transmitted within their memory. One of the important knowledge to have while doing the process of adaptation is the understanding of the cultural background of the folklore. Not only how the language was used or how the landscape of the setting was depicted, but also in how the characters fashioned themselves with clothing appropriate to their culture and how they act and think as a manifestation of the cultural values that is a part of the creative message behind every folk literature. All of these need to be appropriately addressed so that the resulting visual media can retain the educational function of the folklore.

In the process of adapting verbal medium to visual media, illustration plays an important role. Illustration is not only fulfilled decorative aspects of a visual media, but also to communicate a message through the use of visual elements within the illustration. As stated by Wigan, illustrations can visually communicate content in imaginative, distinctive and highly personal ways while solving problems, decorating, storytelling, entertaining, informing, and educating (Wigan). Illustration then becomes a central feature in designing an age-appropriate visual media to transmit the values behind folk literature by entertaining, educating, and engaging the children's imagination. In relation to its role in visualizing the folk literature while communicating a message, an illustration needs to consider cultural and social values that represents certain community and are implied within the folklore. This was also stated by Quental who said folklore indicates the set of customs, legends, proverbs, and artistic expressions that is common to us as a people while also quite distinctive from the dominant majority (Quental).

There are many visual elements that contribute into the process of designing a visual media, one of them is color. Sriwitari and Widnyana argued that color has an important role to transmit a message through its usage in the visual media (Sriwitari and Widnyana). As every community in the cultural setting has their own interpretation of the meaning behind a color, an appropriate use of color can make or break the resulting media in the art of adaptation. Bazin argued in Purton that when doing an adaptation from a verbal to a visual medium, what matters is the equivalence of meaning of the form and not the faithfulness to the original form (Purton). This equivalence of meaning is an alteration needed to be done in order to create an age-appropriate visual media for children by using the visual elements, especially color as described above in the visualization of characters, settings, and storyline.

To further understand about the process of adapting folk literature to visual media, this paper will discuss a case study related to one of the Indonesian fairytale that was adapted into the form of animated film by Ahmad Khan Hakim in 2018, Bawang Merah Bawang Putih ( 
a fairytale where there is no evidence of it being happened before and there were no constraints on the specific time and location. There are many versions of Bawang Merah Bawang Putih exist in Indonesia, however the core message is still the same; it teaches a moral value that kindness will bring fortune and happiness while evil will only bring disaster. This message is indeed a universal one and has a high possibility to be assimilated in any cultural background. Without any specifications on the time and location of the story, it will be interesting to discuss the creative process behind the art of adaptation while designing the illustration related to the three aspects of the story: the characters, the background setting, and the plot or storyline.

\section{The characters}
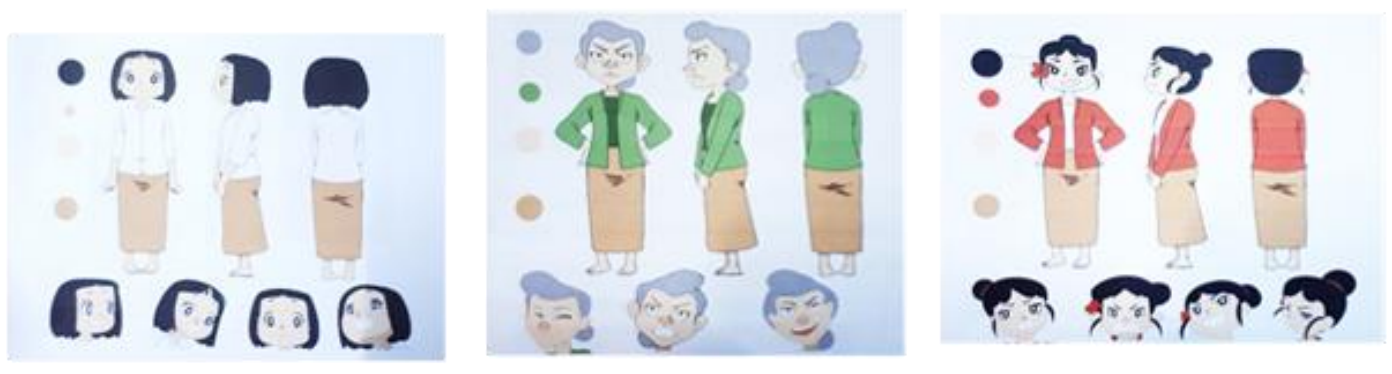

Fig 1. The illustration of the three main characters in Bawang Merah Bawang Putih

Immediately from the fig. 1 we see some similarities in the color used to illustrate the character. The color brown is very prominent in all the three characters. The brown color was applied in all of the clothing for the characters. Wijayatno and Sudrajat wrote that the color of brown is one of the colors that can symbolize ones religiosity in the ancient Javanese culture (Wijayatno and Sudrajat). The application of brown color into the outfits brings an aspect of tradition and immediately evokes a sense of morality in relation to the overall plot of the story. In figure 1(a), Bawang Putih who was depicted as an innocent girl in the story was visualized in the white clothing.

The main characters in this story usually consist of three women, Bawang Putih as the main protagonist, Bawang Merah as the main antagonist, and the Stepmother as the second antagonist. The character illustration can be seen in figure 1. Figure 1(a) shows Bawang Putih, Figure 1(b) shows Bawang Merah, and Figure 1(c) shows the Stepmother. The white here alludes not only to her name, which literally means "white onion", but also to the concept of purity and innocence. Her big eyes coupled with round face and short hairs are designed to enforce the sense of child's purity and a kind soul. In figure 1(b), Bawang Merah who was depicted as arrogant and full of anger in the story was visualized in the red clothing. The red color alludes not only to her name, which literally means "red onion", but also to the concept of anger and jealousy. Her sharp eyes coupled with a red flower attached to the hair and her overall rigid features are designed to enforce the sense of power and the love of materialistic beauty. In figure 1(c), the Stepmother who was depicted as full of greed and cruel in the story was visualized in the green clothing. The green here alludes to the concept of greed and envy. Her overall 
sharp feature that can be seen in her eyes, nose, and jaw lines are designed to enforce the sense of cruelty and an imposing figure.

\section{The background settings}

There are three visualizations of the background setting in figure 2. As we can see, the color used was not the color naturally found in the real world. The combination of orange and grey to visualize the far away sceneries give this animation a fantasy-like vibes. The color of light brown mixed with yellow and light green applied to the plantations gave a sense of enchantment. To further bask the whole animation in a fantasy-like vibes, instead of only using yellow to visualize sunrays, the animation uses a mixture of light violet and white to bring a sense of a world within a dream.

There is one prominent background setting featured in this adaptation of Bawang Merah Bawang Putih, the forest. In this adaptation, their home was located near the forest and there were many activities happening related to the forest. Some of the visualization of the forest can be found in figure 2 appeals to children and younger audience.
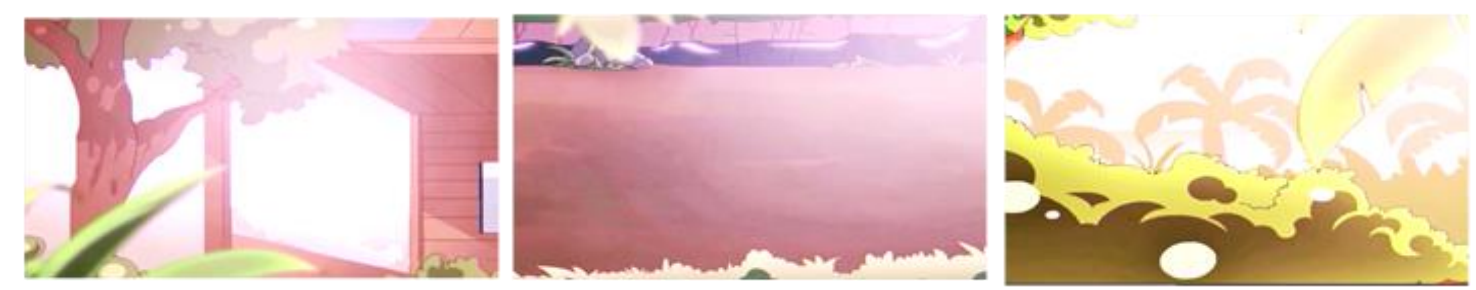

Fig 2. The Background Setting in Bawang Merah Bawang Putih

\section{Plot and settings}

The plot in Bawang Merah Bawang Putih progressed by showing the nature of binary opposition. The sense of happiness will be followed quickly by the sense of sadness. The sense of fear will be followed by the sense of gratitude. Good versus evil has been emphasized strongly throughout the storyline progression. Thus, it is necessary to choose the appropriate color to represent this binary opposition as a core storyline as seen in figure 3.

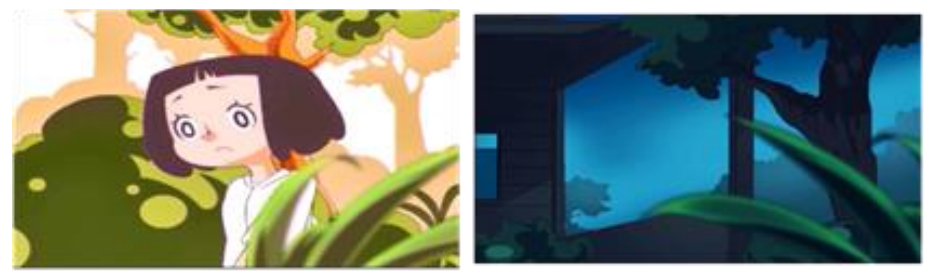

Fig 3. The Binary opposition of color used to enforce the storyline

\section{Conclussion}

Mapping the message intended to be transmitted is crucial when adapting the verbal or written media such as folk literature into a visual media as a part of the creative 
process found in the art of adaptation. This is especially true when designing an ageappropriate visual media for the children. The knowledge about the culture where the folklore originated needs to be applied to the creative process so that it can create the equivalence of meaning in comparison to the original form. In the case of Bawang Merah Bawang Putih presented in this paper, the absurd notion of binary opposition has found its equivalence in the form of color coding. Each of the characters, the background setting, and the storyline is coded in a well-thought color placement that is appealing to children while still subtly focusing on the educational function of teaching the concept of good versus evil. Thus, a deep understanding of the culture and the folklore, not only the story but also the characters and the background location depicted is needed in order to design an appealing visual media for children while still retaining the cultural values shared within the society.

\section{References}

Adi, Danendro. "Memaknai Bahasa Visual Pada Ilustrasi Bergambar Soeharto Di Sampul Muka Majalah Tempo." Humaniora, vol. 5, no. 2, 2014, pp. 612-623, doi:https://doi.org/10.21512/humaniora.v5i2.3118.

Blank, Trevor J. "Toward a Conceptual Framework for the Study of Folklore and the Internet." Folklore and the Internet: Vernacular Expression in a Digital World, edited by Trevor J Blank, University Press of Colorado, 2009.

Cavallaro, Dani. Anime and the Art of Adaptation: Eight Famous Works from Page to Screen. McFarland, 2010.

Danandjaja, James. Folklor Indonesia Ilmu Gosip. Pustaka Grafitipers, 1986.

Gillespie, David. "The Art of Literary Adaptation and English-Language Film Interpretations of Russian Literature ('Anna Karenina')." Procedia-Social and Behavioral Sciences, vol. 154, 2014, pp. 30-35, doi:https://doi.org/10.1016/j.sbspro.2014.10.107.

Hakim, Achmad Khan. "Perancangan Film Animasi Bawang Merah Bawang Putih Sebagai Perjuangan Mendapatkan Kasih Sayang Keluarga." Desain Komunikasi Visual, vol. Sarjana, Tugas Akhir, Universtias Indraprasta PGRI, 2018.

Purton, Valerie. "Nobody's Fault': Little Dorrit, Andrew Davies and the Art of Adaptation." Journal of Victorian Culture, vol. 15, no. 1, 2010, pp. 131-135, doi:https://doi.org/10.1080/13555501003607743.

Quental, Joana. "Searching for a Common Identity: The Folklore Interpreted through Illustration." Journal of Illustration, vol. 1, no. 1, 2014, pp. 9-27, doi:https://doi.org/10.1386/jill.1.1.9 1. 
The Art of Adaptation: From Folk Literature to the Age-Appropriate Visual Media

Setyawan, Arief et al. "Muatan Pendidikan Karakter Dalam Cerita Rakyat Di Pacitan." Jurnal Pendidikan Karakter, vol. 7, no. 2, 2017, doi:http://dx.doi.org/10.21831/jpk.v7i2.21778.

Sriwitari, Ni Nyoman and I. Gusti Nyoman Widnyana. Desain Komunikasi Visual. Graha Ilmu, 2014.

Wigan, Mark. The Visual Dictionary of Illustration. Ava Publishing, 2009.

Wijayatno, Waluyo and Unggul Sudrajat. Keris Dalam Perspektif Keilmuan. Direktorat Jenderal Kebudayaan, 2011. 